\title{
DIVERSITY AND ANTAGONISTIC ACTIVITY OF ACTINOMYCETE STRAINS FROM MYRISTICA SWAMP SOILS AGAINST HUMAN PATHOGENS
}

\author{
Rinoy Varghese ${ }^{1}$, Jyothy $\mathbf{S}^{1}$, A.A. Mohamed Hatha ${ }^{2}$ \\ ${ }^{1}$ School of Environmental Sciences, Mahatma Gandhi University, Kottayam, Kerala, India. \\ ${ }^{2}$ Department of Marine Biology, Microbiology and Biochemistry, Cochin University of Science and Technology, \\ Cochin, Kerala, India.
}

\begin{abstract}
A bs tract
Under the present investigation Actinomycetes were isolated from the soils of Myristica swamps of southern Western Ghats and the antagonistic activity against different human bacterial pathogens was evaluated. Results of the present study revealed that Actinomycetes population in the soils of Myristica swamp was spatially and seasonally varied. Actinomycetes load was varied from $24 \times 10^{4}$ to $71 \times 10^{3}$, from $129 \times 10^{3}$ to $40 \times 10^{3}$ and from $31 \times 10^{4}$ to $84 \times 10^{3}$ in post monsoon, monsoon and pre monsoon respectively. A total of 23 Actinomycetes strains belonging to six genera were isolated from swamp soils. Identification of the isolates showed that most of the isolates belonged to the genus Streptomyces (11), followed by Nocardia (6), Micromonospora (3), Pseudonocardia (1), Streptosporangium (1), and Nocardiopsis (1). Antagonistic studies revealed that $91.3 \%$ of Actinomycete isolates were active against one or more tested pathogens, of that 56.52\% exhibited activity against Gram negative and $86.95 \%$ showed activity against Gram positive bacteria. 39.13\% isolates were active against all the bacterial pathogens selected and its inhibition zone diameter was also high. 69.5\% of Actinomycetes were exhibited antibacterial activity against Listeria followed by Bacillus cereus (65.21\%), Staphylococcus (60.86\%), Vibrio cholera (52.17\%), Salmonella (52.17\%) and E. coli (39.13\%). The results indicate that the Myristica swamp soils of Southern Western Ghats might be a remarkable reserve of Actinomycetes with potential antagonistic activity.
\end{abstract}

Key words: Myristica swamp, Soil, Actinomycetes, Pathogens, Antibacterial Activity

\section{INTRODUCTION}

Actinomycetes are aerobic, gram-positive bacteria. They are one of the main group of soil population and are very widely distributed (Kuster, 1968). Actinomycetes have typical biological aspects such as mycelial forms of growth that accumulates in sporulation. Diversity and load of Actinomycetes in a particular soil would be very much influenced by soil temperature, soil type, soil $\mathrm{pH}$, organic matter content, vegetation, aeration, moisture content etc. Based on several studies among bacteria, the Actinomycetes are striking as antibiotic producers, making three quarters of all known products; the Streptomyces are especially productive (Saadoun and Gharaibeh, 2003). Many of our best known and most valuable antibiotics are produced from Actinomycetes and these include novobiocin, amphotericin, vancomycin, neomycin, gentamycin, chloramphenicol, tetracycline, erythromycin, nystatin, etc. (Oskay et al. 2004).

According to the World Health Organization (WHO), over-usage and the inappropriate and indiscriminate uses of antibiotics have led to the establishment of antibiotic resistance in various bacterial pathogens. Currently, the drug - resistant strains of pathogen come out more rapidly than the rate of invention of new drugs and antibiotics. Rising numbers of antibiotic unresponsive infectious disease agents tackle patients globally [Levy, 2002; Livermore, 2003]. So, we require to isolating and monitoring more and more Actinomycetes from different sources in hope to discover new Actinomycetes strains that can create antibiotics that have not been discovered so far and active against drug - resistant pathogens.

Corresponding a u thor:

Rinoy Varghese, Research Scholar, School of Environmental Sciences, Mahatma Gandhi University, PD Hills PO, Kottayam, Kerala, India - 686560

Email: renochirackal@gmail.com, Fax: 914812732620 
Hence, there is a renewed attention in discovering novel classes of antibiotics that have different mechanisms of action (Spizek and Tichy, 1995; Barsby et al. 2001).

Myristica swamps were first reported by Krishnamoorthy (1960) from the Kerala region of South Western Ghats. These swamps were found in the valleys of Shendurney, Kulathupuzha and Anchal forest ranges in the southern Western Ghats. The distinctive characteristic of the Myristica swamps is the abundance of trees belonging to the family Myristicaceae. It has been projected in the previous studies (Chandran et al. 1999; Varghese, 1992) that the Myristica swamps require particular non biotic environment such as flat bottomed or gently sloping valleys in between heavily forested hills of evergreen forests, deep soil in the adjoining hills with rock below which will allow water to be stored above the rock layer, slow seepage of water from the side hills into the valley throughout the year, heavy annual rainfall averaging $3000 \mathrm{~mm}$ and temperature ranging from 20 to $30^{\circ} \mathrm{C}$. Hence these swamps are highly restricted in distribution. There is no published literature on the diversity and antibiotic potential of Actinomycetes in the soils of Myristica Swamps. Therefore the present study is aimed at isolating Actinomycetes from the soil samples of Myristica swamps and ascertains their antibacterial properties.

\section{MATERIAL AND METHODS}

Locale of the study: Shendurney Wildlife Sanctuary, Southern parts of Western Ghats lies between $8^{\circ} 50^{\prime} \mathrm{N}-8^{\circ} 55^{\prime} \mathrm{N}$ latitude and $77^{\circ} 5^{\prime} \mathrm{E}-77^{\circ} 15^{\prime} \mathrm{E}$ longitude in Kollam District, Kerala, India. Most of the land in this area is covered by evergreen forest and patches of Myristica swamps and the annual rainfall is $320 \mathrm{~cm}$. The mean temperature in summer and winter are $35^{\circ} \mathrm{C}$ and $16^{\circ} \mathrm{C}$ respectively. For the present study we selected 4 sites in Myristica Swamps for soil collection.

Sample Collection: Soil samples were collected from prefixed four sites (MS1 - MS4) of Myristica swamp at a depth of 15 to $20 \mathrm{~cm}$ from the surface. Each of the sampling sites, subsamples of soils were collected from different spot, joint as one and homogenized so as to get representative samples. Sampling was carried out through post-monsoon, pre-monsoon and monsoon seasons. Collection was carried out by a spade that was carefully cleaned and disinfected between sampling so as to avoid cross-contamination.

Isolation, Enumeration and maintenance of Actinomycete: Standard serial dilution plate technique was used for the isolation and enumeration of Actinomycetes. Ten grams of soil was transferred to $90 \mathrm{ml}$ sterile distilled water and stirred vigorously. Different aqueous dilutions, $10^{-1}$ to $10^{-5}$ of the suspensions were prepared and spread plated on Kusters Agar. Nystatin $(50 \mathrm{~g} / \mathrm{ml})$ or Amphotericin $(75 \mathrm{~g} / \mathrm{ml})$ and Streptomycin $(25 \mathrm{~g} / \mathrm{ml})$ were added to the isolation media in order to prevent fungal and bacterial contamination respectively. The plates were incubated at room temperature for 2 to 3 weeks. After incubation Actinomycetes colonies were counted and the load of Actinomycetes was expressed as number of colony forming units (CFU) per gram of soil. After counting, separate colonies were streaked on to Kusters Agar plates and incubated at room temperature for 4-6 days to obtain pure cultures.

Identification of Actinomycetes: Actinomycete isolates which are maintained as pure cultures on Kusters Agar were characterized by morphological tests as per Bergeys Manual of Determinative Bacteriology (Holt et al. 1994) and physiological tests (Gordon, 1967). The morphology of Actinomycetes strains was examined using slide culture technique (Holt et al. 1994). Sterile cover slips were placed at an angle in the Actinomycetes growth medium (Kusters Agar) and the mycelia adhering to cover slips were transferred to a slide and examined at 40x and 100x magnification using a light microscope (Olympus CH 20i). 
Assessment of antagonistic activity: Young cultures of the selected pathogens (Bacillus cereus, Staphylococcus, Listeria, Vibrio cholera, Salmonella and E. coli) were prepared in nutrient broth. A lawn culture of different pathogens were prepared by swabbing young culture (16-18 h) in glycerol yeast agar and waited for 15 minutes to absorb the culture to the medium. Agar wells ( $3 \mathrm{~mm}$ diameter) were punched in the plates using a sterile gel puncture. Thirty microlitres of a four day old culture of Actinomycetes strains in broth was pipetted in to the wells and plates were incubated for $24 \mathrm{~h}$ at room temperature. After incubation, zone of inhibition around the wells were recorded in $\mathrm{mm}$.

\section{RESULTS AND DISCUSSION}

Spatial and seasonal variation of Actinomycetes population: Actinomycetes population in the soils of Myristica swamp showed spatial and seasonal variations. Actinomycetes load was $17 \times 10^{3}-40 \times 10^{2}, 113 \times 10^{2}-30 \times 10^{2}$ and $21 \times 10^{3}-73 \times 10^{2}$ in post monsoon, monsoon and pre monsoon respectively (Table 1 and Fig. 1). Load of Actinomycetes population was lesser in monsoon season possibly due to struggle for nutrients with plants. Protozoan predation of microorganisms also decreases the number (Bhatt and Pandya, 2006). Actinomycetes population was high in pre monsoon followed by post monsoon and monsoon seasons. Result showed that Actinomycetes were mostly vigorous through pre monsoon season due to enhanced soil temperature, which might favour the microbial activity. In our previous studies (Varghese et al. 2012a, 2012b) in shola and grassland soils of tropical montane forest of Southern Western Ghats also reported that the load of Actinomycetes was high during pre monsoon season. Spatial variation of Actinomycetes in a particular soil was mainly attributed to soil temperature, soil type, soil pH, organic matter content, cultivation, aeration, moisture content etc.

Table 1 Load of Actinomycetes population in Myristica swamps soils during the study period

\begin{tabular}{|c|c|c|c|}
\hline Sampling sites & Post Monsoon & Monsoon & Pre monsoon \\
\hline MS1 & $17 \times 10^{3}$ & $113 \times 10^{2}$ & $21 \times 10^{3}$ \\
MS2 & $40 \times 10^{2}$ & $49 \times 10^{2}$ & $91 \times 10^{2}$ \\
MS3 & $42 \times 10^{2}$ & $30 \times 10^{2}$ & $73 \times 10^{2}$ \\
MS4 & $47 \times 10^{2}$ & $37 \times 10^{2}$ & $86 \times 10^{2}$ \\
\hline
\end{tabular}

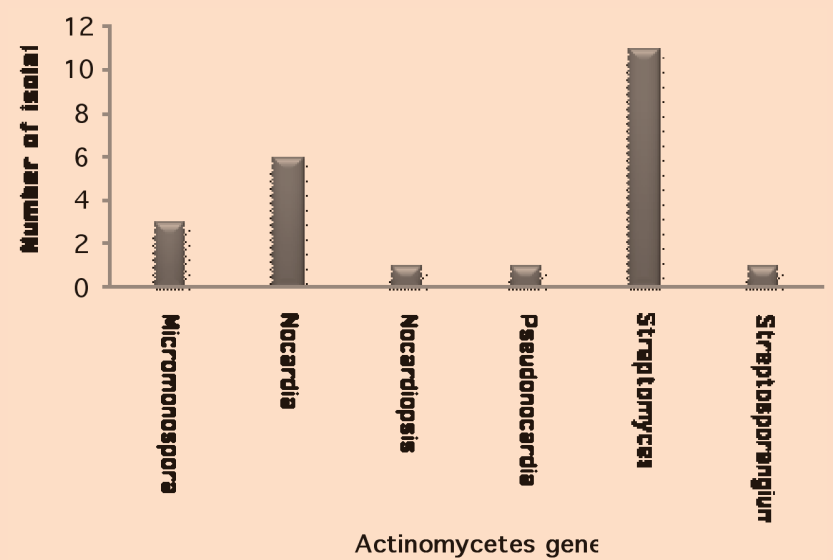

Fig. 1 Generic diversity of Actinomycetes in Myristica swamp soils 
Diversity of Actinomycetes: Characterization of actinomycetes isolates revealed that out of twenty-three isolates collected, most of the isolates belonged to the genus Streptomyces (11), Nocardia (6), Micromonospora (3), Pseudonocardia (1), Streptosporangium (1), and Nocardiopsis (1), (Fig. 1). In our earlier studies (Varghese et al. 2012a, 2012b) reported most of the genera identified during this study from the shola and grassland soils of southern Western Ghats. Different Actinomycete genera were reported from the soils of rainforests of Singapore, among which Streptomyces, Micromonospora, Actinoplanes, Actinomadura, Nonomuria, Nocardia and Streptosporangium were the most abundant (Wang et al. 1999). Balagurunathan et al. (1996) reported many of the genera identified during this study from south Indian soil.

Antibacterial potential of Actinomycetes: Antibacterial studies revealed that 91.3\% of Actinomycete isolates were active against one or more tested pathogens, of that $56.52 \%$ exhibited activity against Gram negative and $86.95 \%$ showed activity against Gram positive bacteria. 39.13\% Isolates were active against all the pathogens selected and its inhibition zone diameter was also high. $69.5 \%$ of Actinomycetes were exhibited antibacterial activity against Listeria followed by Bacillus cereus (65.21\%), Staphylococcus (60.86\%), Vibrio cholera (52.17\%), Salmonella (52.17\%) and E. coli (39.13\%). Diameter of inhibition zone (mm) against test microorganisms are presented in Table 2 and the percentage of antibacterial

Table 2 Antibacterial activity exhibited by actinomycete isolates

\begin{tabular}{|c|c|c|c|c|c|c|}
\hline \multirow[b]{2}{*}{$\begin{array}{l}\text { Isolate } \\
\text { No. }\end{array}$} & \multicolumn{6}{|c|}{ Diameter of inhibition zone $(\mathrm{mm})$ against test microorganisms } \\
\hline & Listeria & $\begin{array}{l}\text { Vibrio } \\
\text { cholera }\end{array}$ & $\begin{array}{l}\text { Bacillus } \\
\text { cereus }\end{array}$ & $\begin{array}{c}\text { Staphylococcus } \\
\text { aureus }\end{array}$ & $\begin{array}{c}\text { Salmonella } \\
\text { typhi }\end{array}$ & $\begin{array}{c}E . \\
\text { coli }\end{array}$ \\
\hline Ms1 & 21 & 17 & 19 & 24 & 12 & 22 \\
\hline Ms2 & 16 & 0 & 11 & 0 & 0 & 0 \\
\hline Ms 3 & 24 & 25 & 21 & 19 & 19 & 32 \\
\hline Ms 4 & 0 & 0 & 13 & 0 & 0 & 0 \\
\hline Ms 5 & 11 & 0 & 0 & 0 & 0 & 0 \\
\hline Ms 6 & 19 & 0 & 16 & 21 & 0 & 0 \\
\hline Ms 7 & 0 & 0 & 0 & 0 & 0 & 0 \\
\hline Ms 8 & 15 & 26 & 0 & 17 & 21 & 0 \\
\hline Ms 9 & 28 & 19 & 23 & 22 & 29 & 28 \\
\hline Ms 10 & 0 & 11 & 0 & 0 & 0 & 0 \\
\hline Ms 11 & 18 & 21 & 22 & 14 & 12 & 21 \\
\hline Ms 12 & 23 & 15 & 18 & 28 & 21 & 27 \\
\hline Ms 13 & 31 & 21 & 29 & 33 & 31 & 21 \\
\hline Ms 14 & 12 & 0 & 0 & 14 & 0 & 0 \\
\hline Ms 15 & 0 & 0 & 0 & 0 & 0 & 0 \\
\hline Ms 16 & 0 & 0 & 0 & 11 & 0 & 0 \\
\hline Ms 17 & 30 & 24 & 32 & 29 & 16 & 0 \\
\hline Ms 18 & 0 & 0 & 11 & 0 & 0 & 0 \\
\hline Ms 19 & 29 & 17 & 24 & 23 & 31 & 23 \\
\hline Ms 20 & 14 & 0 & 0 & 0 & 0 & 0 \\
\hline Ms 21 & 0 & 0 & 13 & 0 & 11 & 0 \\
\hline Ms 22 & 27 & 13 & 26 & 18 & 16 & 17 \\
\hline Ms 23 & 31 & 24 & 28 & 27 & 31 & 20 \\
\hline
\end{tabular}




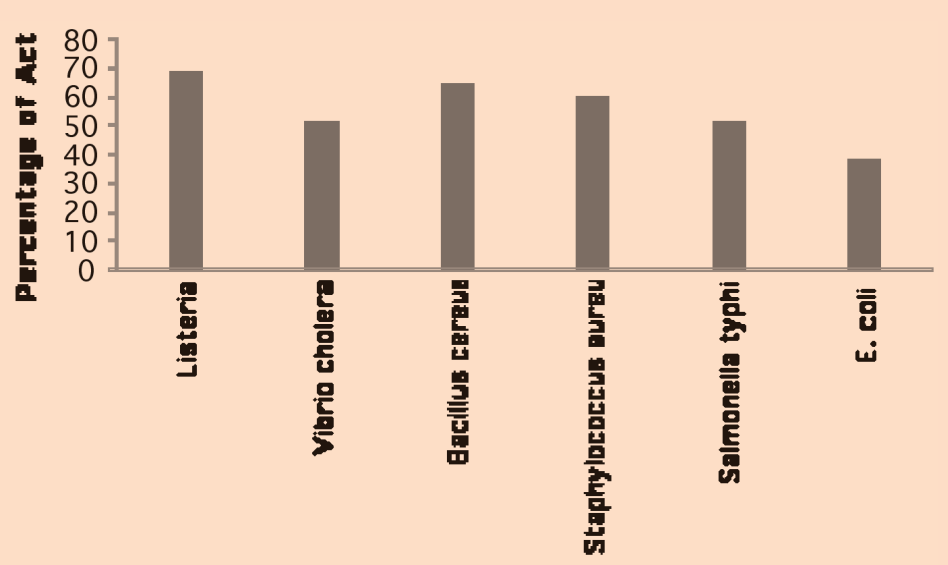

Pathogens

Fig. 2 Percentages of antibacterial activity exhibited by Actinomycete isolates from Myristica swamp soils against specific pathogens

activity exhibited by actinomycete isolates are presented in Figure 2. Antibacterial activity studies revealed that majority of the isolates were active against Gram positive bacteria than Gram negative bacteria. In several earlier reports (Sahin, 2002; Thakur et al. 2007; Varghese et al. 2012a; 2012b), high percentage of activity was exhibited against Gram positive bacteria while Gram negative bacteria were less inhibited. The reason for different sensitivity of Gram positive and Gram positive could be ascribed to the morphological differences between these organisms. Gram negative bacteria have an outer polysaccharide membrane carrying the structural lipo polysaccharide components. This makes the cell wall of Gram negative bacteria impermeable to certain solutes, whereas the Gram positive bacteria have only an outer peptidoglycan layer which is not an effective permeability barrier. This makes Gram positive bacteria more sensitive to antibiotics produced by Actinomycetes (Moncheva et al. 2002). Most of the isolates were also not active against E. coli. The present result about $E$. coli is in tune with the previous reports (Anansiriwattana et al. 2006; Oskay et al. 2004).

\section{CONCLUSIONS}

Load of Actinomycetes in the Myristica Swamp soils were $17 \times 10^{3}-40 \times 10^{2}, 113 \times 10^{2}$ $30 \times 10^{2}$ and $21 \times 10^{3}-73 \times 10^{2}$ in post monsoon, monsoon and pre monsoon respectively. Most of the actinomycetes isolates belonged to the genus Streptomyces, Nocardia, Micromonospora, Pseudonocardia, Streptosporangium, and Nocardiopsis. Antibacterial studies revealed that $91.3 \%$ of Actinomycete isolates were active against one or more tested pathogens, of that $56.52 \%$ exhibited activity against Gram negative and $86.95 \%$ showed activity against Gram positive bacteria. Soils of Myristica swamps of southern Western Ghats have excellent diversity of Actinomycetes population with potential antagonistic activity against human pathogens. New antibiotics are a thrust area; the extraction of antibacterial substances from Actinomycetes of Myristica swamp soils assumes importance. 


\section{REFERENCES}

1. Anansiriwattana W, Tanasupawat S, Amnuoypo S, Suwanborirux K. Identification and antimicrobial activities of actinomycetes from soils in Samed Island and geldanamycin from strain PC4-3. Thai J. Pharm. Sci. 2006; 30, 49-56.

2. Balagurunathan R, Xu L, Jiang C. Diversity of soil actinomycetes from South India and South China. Actino 1996; 4, 89-94.

3. Barsby T, Kelly MT, Gagne SM. Andersen RJ. Bugorol A produced in culture by a marine Bacillus sp. reveals a novel template for cationic peptide antibiotics. Org. Lett. 2001; 3, 437-440.

4. Bhatt SA, Pandya SM. Seasonal changes in microbial biomass and enzyme activities in some soils of western India. Asian Jr. of Microbiol. Biotech. Env. Sc. 2006; 8, 69 -73.

5. Chandran MDS, Mesta DK, Naik MB. Myristica swamps of Uttara Kannada District. My Forest, 1999; 35, 217222 .

5. Gordon RE. The ecology of soil bacteria, TRG Gray and Parkinson, Liverpool University Press, 1967.

6. Holt JG, Krieg NR, Sneath PHA, Staley JT,Williams ST. Bergey's Manual of Determinative Bacteriology. Williams and Wilkins, London, 1994.

7. Krishnamoorthy K. Myristica swamps in the evergreen forests of Travancore. Indian For., 1960; 86, 314-315.

8. Kuster E. The actinomycetes. In: Soil Biology, eds. Burges (A.) \& Raw (F.), Academic Press, London, 1968.

9. Levy SB. The antibiotic paradox: how misuse of antibiotics destroys their curative powers, 2nd (ed), Perseus Books, Boston, 2002.

10. Livermore DM. Bacterial resistance: origins, epidemiology and impact. Clin Infect Dis. 2003; 36, S11-S23.

11. Moncheva P, Tishkov S, Dimitrova N, Chipeva V, Nikolova SA, Nevena K, Bogatzevska N. Characteristics of soil actinomycetes from Antartica. J Cult Collect 2002; 3, 3-14.

12. Oskay M, Tamer AU, Azeri C. Antibacterial activity of some actinomycetes isolated from farming soils of Turkey. Afr J Biotechnol 2004; 3, 441-446.

13. Saadoun I, Gharaibeh R. The Streptomyces flora of Badia region of Jordan and its potential as a source of antibiotics active against antibiotic- resistant bacteria. J. Arid Environ. 2003; 53, 365 - 371.

14. Sahin N. Investigation of the antimicrobial activity of some Streptomyces isolates. Turk J Biol 2002; $27,79-84$.

15. Spizek J, Tichy P. Some aspects of overproduction of secondary metabolites. Folia Microbiol, 1995; 40, 43-50.

16. Thakur D, Yadav A, Gogoi BK, Bora TC. Isolation and screening of Streptomyces in soil of protected forest areas from the states of Assam and Tripura, India, for antimicrobial metabolites. J Mycol Med 2007; 17, $242-249$.

17. Varghese R, Nishamol S, Suchithra R, Hatha AAM. Distribution and Antibacterial Activity of Actinomycetes from Shola Soils of Tropical Montane Forest in Kerala, South India. Journal of Environment 2012b; 01, 93-99.

18. Varghese R, Suchithra R, Nishamol S, Hatha AAM. Spatiotemporal variation and antibacterial activity Of actinomycetes isolated from high altitude Grassland soils of tropical Montane forest - Kerala, India. Studia Univ. VG SSV 2012a; 22, 451-455.

19. Varghese V. Vegetation structure, floristic diversity and edaphic attributes of the fresh water swamp forests in Southern Kerala. B.Sc. Dissertation, Kerala Agricultural University, Vellanikkara, 1992.

20. Wang Y, Zhangm ZS, Ruan JS, Wang YM, Ali SM. Investigation of actinomycete diversity in the tropical rainforests of Singapore. J Ind Microbiol Biotl 1999; 23, 178-187.

Received: February, 2, 2014

Accepted: April, 22, 2014 